\title{
OPEN Author Correction: Modulation of in vitro Brain Endothelium by Mechanical Trauma: Structural and Functional Restoration by Poloxamer 188
}

\author{
Edidiong Inyang, Vinay Abhyankar, Bo Chen \& Michael Cho \\ Correction to: Scientific Reports https://doi.org/10.1038/s41598-020-59888-2, published online 20 February 2020 \\ The Acknowledgements section in this Article was omitted. The Acknowledgements section should read: \\ “This work was supported by a grant (N00014-16-1-2140) from the Office of Naval Research. Edidiong Inyang \\ was a Louis Stokes Alliance for Minority Participation (LSAMP) Fellow".
}

\begin{abstract}
(c) (i) Open Access This article is licensed under a Creative Commons Attribution 4.0 International License, which permits use, sharing, adaptation, distribution and reproduction in any medium or format, as long as you give appropriate credit to the original author(s) and the source, provide a link to the Creative Commons license, and indicate if changes were made. The images or other third party material in this article are included in the article's Creative Commons license, unless indicated otherwise in a credit line to the material. If material is not included in the article's Creative Commons license and your intended use is not permitted by statutory regulation or exceeds the permitted use, you will need to obtain permission directly from the copyright holder. To view a copy of this license, visit http://creativecommons.org/licenses/by/4.0/.
\end{abstract}

(C) The Author(s) 2020 